\title{
Socio-economic Condition of Child Worker of Bangladesh in Their Adulthood: An Econometric Analysis
}

\author{
Syed Imran Ali Meerza (Corresponding author) \\ Economics Discipline, Social Science School, Khulna University \\ Khulna-9208, Bangladesh \\ E-mail: imran.meerza@gmail.com \\ Biswajit Bacher \\ Sociology Discipline, Social Science School, Khulna University \\ Khulna-9208, Bangladesh \\ E-mail: bisbacher@yahoo.co.in
}

\begin{abstract}
This study mainly focuses on the current socio-economic condition of those people who were child labor in their childhood. In this study, economic indicators are income and employment status. On the other hand, level of education, health status and role in case of decision making in the society are studied as social indicators. According to this study, socio-economic condition of child workers in their adulthood is not very satisfactory. This research work have used Linear Probability Model (LPM) and Weighted Least Square (WLS) regression analysis to make comparison of current socio-economic status between people who were child labor in their childhood and those who were not child worker in past. This research study finds that person who was not child worker in early stage of his/her life have higher probability to enjoy better socio-economic condition than that of person who worked as child worker in past. In fact, it identifies that a children who is working as a child worker has $61 \%$ probability to have low standard of living in his/her future life.
\end{abstract}

Keywords: Child labor, Socio-economic condition, Linear probability model

\section{Introduction}

Youth power is very important to take the development strategies for any nation. Still a considerable number of young aged people are involving in economic activities since early ages. Recently emphasize has been given to reduce the proportion of child labor by UNICEF, UNDP, Save the Children of UK, Australia \& Sweden and so many NGOs in Bangladesh like Prodipon and so on. World Vision is also working for the street children. In Bangladesh, total number of children aged 5-14 years is about 35.06 million among which working children is approximately 5.05 million (BBS, 2003). Basically IPEC \& ILO have worked vastly on the dangerous situation of the violations and terrible things of child labor. Recently, ILO estimates that 218 million children worldwide aged 5 to 17 are involved in work of which 126 million works in hazardous conditions. The highest numbers of working children, 122 million, are in the Asia pacific region (ILO website, 2006).

Child labor is a complex problem. It is a controversial and emotional issue. It is also a challenging one that defies simple solutions. The thoughtful and comprehensive approaches required must be guided by the best interests of the child and by a commitment to children's human rights, as enshrined in the convention on the rights of the child. Its roots are deeply embedded in social, economic and cultural structures (Meerza, 2010).

Bhalotra and Heady (2000) has presented a dynamic model of child labor supply in farming household. The model clarifies the roles of land, income and household size, allowing labor and credit market imperfections. If labor markets are imperfect, child labor is increasing in farm size and decreasing in household size.

Salmon (2005) has conducted a study on child labor. He uses data from the Bangladesh Labor Force Survey 2000 (LFS). According to him, the magnitude of child labor problem in Bangladesh is large. Among the poorest quintile of households, the share of family income contributed by child workers reaches nearly 50 percent. Salmon (2005) and Meerza (2010) has identified support for the widely held hypothesis that poverty compels children to work. 
The impact of child labor in the society can not be evaluated in a statement. Children are important part of any society. They can develop a nation. They can prosper a nation and also a country. But child labor is very harmful for the society. If anyone is labor since early age, they must hamper their physical and educational life. Thus, they can not develop their future life. The concepts of child labor and child education both are inversely linked with each other in terms of execution. Child labor does not allow child education and vice versa (Hosen et al. 2010). Eventually few adult people are in better position though they provided efforts as child labor at early ages. But the maximum number is at vulnerable position. So this study is very urgent to focus on the socio-economic characteristics of the adults who were worked as a child worker at their early ages in order to indicate the barriers for glorious future life and to focus on their current positions. Although there is a significant body of literature on the economics of child labor but till now we do not find any research article which mainly has shown the negative effects of child labor on the future life of those children and what type of standard of living they achieve when they grow up which is very important in order to see the long term effect of child work. So, the main objective of this study is to evaluate the overall situation from socio-economic perspective of the adults who were child labor at their early ages.

\section{Methods}

The methodological approach to this study is based on primary data through face to face interview. The data for this study has collected from Khulna city of Bangladesh. The financial and temporal constraints are the main reasons for selecting small sample size. A purposive sampling is adopted to select city and covered 240 respondents. At first, this study has used cluster sampling and identified two clusters one is those who were worked as child worker at their early age and another cluster belongs to those who were not child worker in their early period of life. Moreover, in case of each cluster a quota of 120 respondents has fixed in order to ensure equal participation of both clusters. Under quota sampling, respondents are selected randomly. In this study, data is restricted to those respondents whose age is between 30 to 50 years. The analysis done in this study is based on a data set with an explicit focus on the socio-economic condition of those who were child worker during their childhood. This study has also used limited secondary data which are mainly obtained from multiple documents including published books and journal articles. In this study, we have used some definitional terms such as child labor, adult age, later age and socio-economic determinants. The term child labor in this research work means an economic activity conducted by a person below the age of 15 . This definition will be the operational definition of 'child' used in this study. On the other hand, later age indicates aged group of people above 15 years who are able to participate physically and mentally in all types of work and who are also able to participate in decision making in the society. In this research, socio-economic determinants indicate the educational qualification, income and expenditure level, current job status, access to proper sanitation, migration status, incidence of chronic disease, health inputs such as vaccinations and scope in society's decision making process.

\section{Results and Discussions}

\subsection{Socio-economic condition of persons who worked as child worker in their childhood}

In this section, we have analyzed employment status, level of education and monthly income etc. of those who were child labor in past. So, in this section sample size is 120. If we compile the findings, we can get the facts as illustrated below:

In case of education, a largest number of respondents among those who were child labor in their early age are illiterate amounting $35 \%$ whereas around $32 \%$ of them have passed the primary education but only $0.8 \%$ has passed higher secondary level. It depicts that most of the respondents are illiterate (see table 01). Consequently, about $64 \%$ of the respondents are now working as day laborer, approximately $23 \%$ are petty businessman, $8 \%$ are service holder and only 5\% of them are the businessman (see table 02 ). In addition, about $36 \%$ of the respondents' monthly income is ranging from 57 USD to 86 USD while less than $1 \%$ respondents are now in their adulthood earning 200 USD to 230 USD per month. Here, average income is approximately 76 USD which is very low (see table 03 ).

A very few number of respondents such as around $4 \%$ participate in decision making of society on the other hand about $90 \%$ do not engage in the decision making process of the society (see table 04 ).

\subsection{Model estimation}

In this model, our sample size is 240 where 120 respondents were child worker and another 120 respondents were not child worker in past. The main aim of this model is to find out the probability of a person who was child labor to have low standard of living in their adulthood as compared to those who were not child worker.

Our model specification is as follows 
$Y_{i}=\alpha+\beta_{1}(\operatorname{In})_{i}+\beta_{2}(E x)_{i}+\beta_{3} D_{1 i}+\beta_{4} D_{2 i}+\beta_{5} D_{3 i}+\beta_{6} D_{4 i}$

Where, $Y_{i}=1$ if the respondent was child labor in early age

0 otherwise

In $=$ Monthly income of the respondents

$E x=$ Monthly expenditure of the respondents

$D_{1}=1$ if rural migrant (those who migrate from rural to urban area) 0 otherwise

$D_{2}=1$ if all vaccinations have received 0 otherwise

$D_{3}=1$ if have access to proper sanitation 0 otherwise

$D_{4}=1$ if have chronic diseases 0 otherwise

$\alpha=$ intercept, on the other hand, $\beta_{1}, \beta_{2}, \beta_{3}, \beta_{4}, \beta_{5}$ and $\beta_{6}$ are slope coefficients

Since dependent variable of this model is dummy variable or dichotomous variable, we can use any of the following models: linear probability model, the logit model, the probit model and the tobit (censored regression) model. In this study, we have used linear probability model (LPM) which mainly shows that the dichotomous variable as a linear function of the explanatory variables. Based on our primary data the LPM estimated by Ordinary Least Square (OLS) as follows:

$$
\begin{aligned}
& \hat{Y}_{i}=1.009-0.004(I n)-0.011(E x)+0.059 D_{1}-0.141 D_{2}-0.452 D_{3}+.09 D_{4} \\
& \left.\begin{array}{lllllll}
(0.046) & (0.002) & (0.003) & (0.031) & (0.038) & (0.043) & (0.032
\end{array}\right) \\
& \mathrm{R}^{2}=0.825 \quad \text { adjusted } \mathrm{R}^{2}=0.825 \quad \mathrm{~F}=182.457
\end{aligned}
$$

In LPM, estimators, $\hat{Y}_{i}$, need to be necessarily positive or less than one but this is not satisfied for all the values. Even if the estimated $\hat{Y}_{i}$ were all positive and less than one, LPM still suffers from the problem of heteroskedasticity (Gujarati, 1998). So we need to remove the problems of normality of disturbances $\mathrm{u}_{\mathrm{i}}$, heteroskedastic variances of the disturbances and non fulfillment of $0 \leq \mathrm{E}\left(\mathrm{Y}_{\mathrm{i}} / X\right) \leq 1$ in case of linear probability model. In order to solve those limitations and to obtain more efficient estimates of the standard errors, we will use Weighted Least Square (WLS) regression analysis. So, WLS regression is

$$
\begin{aligned}
& \hat{Y}_{i}=1.072-0.007(\text { In })-0.011(E x)+0.048 D_{1}-0.125 D_{2}-0.453 D_{3}+.081 D_{4} \\
& \begin{array}{ccccccc}
(0.029) & (0.002) & (0.002) & (0.018) & (0.028) & (0.045) & (0.024) \\
* * & * * * & * * & * * * & * * * & * * * & * * *
\end{array}
\end{aligned}
$$

Where, $* * *$ indicates significant at $1 \%$ level and $* *$ implies significant at $5 \%$ level.

$\mathrm{R}^{2}=0.963$ adjusted $\mathrm{R}^{2}=0.961 \mathrm{~F}=658.763$

In the above equation, each slope coefficients gives the rate of change in the conditional probability of the event occurring for a given unit change in the value of the explanatory variable. From this equation, we can see that those who were child labor at their childhood have less monthly income as compared to those who were not child worker at their early age. In addition, in case of access to proper sanitation and not having chronic diseases, respondents who were not child worker in early stage of their life have higher probability in case of access to proper sanitation and not having chronic diseases as compared to respondents who were working in their childhood. We have also found that most of the respondents of our study who worked as child labor are mostly rural migrant which also supports outcome of Meerza (2010) that child labor is a severe problem in the rural areas of Bangladesh. In addition, from the above equation we find that the probability of a person who worked as child worker in past have less income, less access to proper sanitation, less likely to receive all vaccinations, more likely to have chronic disease and likely to be migrated is 0.61 which implies that 61 respondents out 100 respondents who worked in their childhood are getting poor socio-economic condition in their adulthood.

$1.072-0.007-0.011+0.048-0.125-0.453+0.081=0.605$ or around 0.61 (or $61 \%$ ) 


\section{Recommendations}

There is lack of adequate statistics on child farm labor in Bangladesh. To determine the nature of child farm labor a regular and comprehensive survey is necessary. Some features on child labor can be included in the questionnaire of national census. Moreover, extensive research must be taken in order to develop effective national (and international) policies and programs in order to reduce the incidence of child labor. Learning through earning should be the focus for special schools for working children where food or tiffin, dress and stipends will be provided. The school hours will be fixed in accordance to the working time of child farm workers. Guardians of child farm workers are not aware of child laws and child rights. Government should promote awareness of child labor issues nation wide with the help of NGOs and media in the general community. These awareness-raising campaigns may be introduced in the schools including special schools for working children. In this case, broad social alliance may be effective. Government actions against child labor often end with making laws. Initiatives against child labor traditionally come from non governmental organizations that have limited resources. So, both governmental and non governmental organizations should work together.

We find out that person who worked as child worker are significantly less likely to be received all vaccinations. In this case both government and NGOs can introduce the door-to-door vaccination services.

\section{Conclusion}

The prevalence of child labor is more or less seen in all periods of time, it varies in nature and dimension depending on the existing socioeconomic structure of the society. Children are the blooming flowers of the garden of a society and valuable asset of a nation. They constitute a hidden treasure of potential development of a growing nation, childhood has been considered as a most important period of life. During this period moulding and shaping of the life take place and the behavior, conduct and sentiments are developed. Paradoxically, it is unfortunate to say that tragically most of the child life is lost due to child work. Child labor is mainly necessitated by economic compulsions of the parents in many cases of the children. The main reason which give rise to child labor are widespread of absolute poverty, unemployment and underemployment among the adult workers, large families, lack of educational facilities, illiteracy and ignorance of parents about the importance of education as well as about the impact of labor on the health of their children are some of the reasons which breed child labor.

Most people in Bangladesh live under poverty line and many begin to work at very early age. Children are found working under hazardous conditions such as mining, auto repair, battery recharging, saw milling, welding, rickshaw pulling, garments manufacturing and working with dangerous machinery. It is clear from this study that child labor has higher probability to create negative impacts on future life. Since child worker does not get opportunity to get better education, they can not get better job opportunities in future life. Consequently, their income remains low which only ensure low standard of living. So, poverty and illiteracy are the main causes for leading child labor. Consequently, the vulnerable socio-economic status at adulthood is caused by hazardous child labor. If we can ensure the pragmatic educational program and vocational training to make them skilled, then the negative effects of child labor on later age can be reduced significantly.

\section{References}

Anker, R. (2000). The Economies of Child Labor: A Framework for Measurement. International Labor Review, 139, 257-280.

Baker, R and Brick, C. P. (2000). A Comparative Perspective on Children's Careers and Abandonment in Nepal. Cambridge University Press, UK.

Bangladesh Bureau of Statistics. (2003). Progotir pathey. Ministry of Planning, Government of Bangladesh, Dhaka, Bangladesh.

Basu, K. (1999). Child Labor: Cause, Consequence and Cure. Journal of Economic Literature, 37 (3), 1083-1119.

Basu, K. and et al. (2010). Child Labor and Household Wealth: Theory and Empirical Evidence of an Inverted-U. Journal of Development Economics, 91 (1), 8-14.

Bhalotra, S. and Heady, C. (2000). Child Farm Labor: Theory and Evidence. Mimeograph, Cambridge, UK.

Greene, W.H. (2004). Econometric Analysis. (5 ${ }^{\text {th }}$ ed.). Pearson Education, Singapore.

Gujarati, D.N. (1998). Basic econometrics. ( $3^{\text {rd }}$ ed.). McGRAW-HILL, New York, USA. 
Hosen, M.A. and et al. (2010). Child Labor and Child Education in Bangladesh: Issues, Consequences and Involvements. International Business Research, 3 (2).

ILO. (2006). The End of Child Labor: Within Reach. International Labor Force, Geneva.

Meerza, S.I.A. (2010). Rural-Urban Migration and Its Consequences on Rural Children: An Empirical Study. Asian Social Science, 6 (12), 176-181.

Meerza, S.I.A. (2010). Role of Rural-Urban Migration in Increasing Rural Child Labor: A Case Study on Khulna District of Bangladesh. VDM-Verlag, Germany.

Moore, K. (2000). Supporting Children in Their Working Lives: Opportunities and Obstacles Within the International Policy Environment. Journal of International Development, 12 (4), 531-548.

Nieuwenhuys, O. (1996). The Paradox of Child Labor and Anthropology. Annual Review of Anthropology, 25, 237-251.

Salmon, C. (2005). Child Labour in Bangladesh: Are Children the Last Economic Resources of the Household. Sage Publication, University of Savoie, France.

Volticos, N. (1998). International Labor Standards and Human Rights: Approaching the Year 2000. International Labor Review, 137 (2), 135-147.

Table 1. Educational qualification of the respondents

\begin{tabular}{|c|c|c|}
\hline Level of education & Number of respondents & Percentage \\
\hline Illiterate & 42 & 35.0 \\
\hline Class 1 to 5 (Primary) & 38 & 31.7 \\
\hline Class 6 to 8 & 20 & 16.7 \\
\hline Class 9 to S.S.C. & 19 & 15.8 \\
\hline H.S.C. & 1 & 0.8 \\
\hline Total & 120 & 100.0 \\
\hline
\end{tabular}

Source: Field Survey, 2009

Table 2. Occupation of the respondents

\begin{tabular}{|c|c|c|}
\hline Types of occupation & Number of respondents & Percentage \\
\hline Labor & 77 & 64.2 \\
\hline Petty Businessman & 27 & 22.5 \\
\hline Businessman & 6 & 5.0 \\
\hline Service Holder & 10 & 8.3 \\
\hline Total & 120 & 100.0 \\
\hline
\end{tabular}

Source: Field Survey, 2009 
Table 3. Monthly income of the respondents

\begin{tabular}{|c|c|c|c|}
\hline Income level (in USD) & $\begin{array}{c}\text { Number of } \\
\text { respondents }\end{array}$ & Percentage & Average \\
\hline $0-29$ & 18 & 15.0 & \\
\hline $29-57$ & 24 & 20.0 & \\
\hline $57-86$ & 43 & 35.8 & \\
\hline $86-114$ & 20 & 16.7 & \\
\hline $114-143$ & 5 & 4.2 & \multirow{2}{*}{76.00} \\
\hline $143-171$ & 2 & 1.7 & \\
\hline $171-200$ & 3 & 2.5 & \\
\hline $200-229$ & 1 & .8 & \\
\hline $229-257$ & 2 & 1.7 & \\
\hline $257-286$ & 2 & 1.7 & \\
\hline Total & 120 & 100.0 & \\
\hline
\end{tabular}

Source: Field Survey, 2009

Table 4. Decision making in the society by the respondents

\begin{tabular}{|c|c|c|}
\hline Taking part in decision making & Number of respondents & Percentage \\
\hline Yes & 5 & 4.2 \\
\hline Sometimes & 8 & 6.7 \\
\hline Not at all & 107 & 89.2 \\
\hline Total & 120 & 100.0 \\
\hline
\end{tabular}

Source: Field Survey, 2009 